Бімал Тріведі

Магістр нумізматики та археології

Університет Мумбаї

(Мумбаї, Індія)

\section{Bimal Trivedi}

MA in Numismatics and Archaeology

Mumbai University

(Mumbai, India)

bimaltrivedi@gmail.com

ORCID: 0000-0001-6769-3989

\title{
COINAGE OF THE INDO-GREEKS CHALLENGES OF THE ANCIENTS AND THE SOLUTIONS IN THE MODERN WORLD
}

\section{ІНДО-ГРЕЦЬКІ МОНЕТИ: ВИКЛИКИ ДРЕВНІХ ТА РІШЕННЯ В СУЧАСНОМУ СВITI}

\begin{abstract}
.
When Alexander had to leave his conquest of India midway, some of his generals stayed back to rule the conquered north-west India the part which was known as Bactria. These Kings and generals held sway and minted their coins with pure Hellenistic motifs, scripts/legends, and styles. By the middle of the 2nd century BCE, by the inclusion of the Indian script Kharoshthi, Indian elements started appearing and became mainstream. Not only the legend but the weight standard was changed and the Indian standard was adopted. This was the most important change. Problems: The vast sum of Indo-Greek coinage has been unearthed so far but had remained under-studied for more than one reason. As it remains, the problem areas have remained unaddressed and unanswered. This has mainly happened due to the study of coinage in isolation far away from the find spots and devoid of stratigraphy and ignoring local knowledge of the subject. This situation has been aggravated by political turmoil and insulating archaeological finds and records by limiting the access combined with poor local scholarly work or absence of scientific approach due to poor economic conditions and access to modern methods and technology to approach, enhance, and understand the historically very important Indo-Greek coinage. Unfortunately, Indo-Greek coinage study is clubbed with Hellenistic outlook and mostly aggravated by vogue historicity. Scope of Study: This paper highlights challenges in studying Indo-Greek coinage and other factors that have not been addressed and difficulties in the way of scholarly pursuit. A modern tech-driven approach is recommended for addressing the challenges. Scientific Evaluation: A more technology-driven approach to study the Indo-Greek coinage will unravel the mysteries and remove the historical blind spots. Exclusively treating the subject of Indo-Greek coinage and thus providing recognition it deserves as unique, de-
\end{abstract}


bracketed from Hellenistic coinage. Conclusions: The modern technology-driven data management scientifically adopted archaeological exploration and excavation paired with the latest Information Technology tools including the use of social media platforms can be networked effectively to build up a fresh modern repository of findings that will help historians, archaeologists, scholars, students, and numismatists/collectors.

Key words: Indo-Greeks, scientific research problematics, Bactria, Indian numismatics.

\section{Анотація.}

Коли Олександрові довелося полишити ідею завоювання Індії на півдорозі, деякі з його полководиів повернулися, щуоб керувати завойованою північнозахідною частиною Індіі, яка була відома як Бактрія. Ці правителі-полководиі отримали владу і карбували свої монети із суто елліністичними мотивами, сценаріями/легендами та стилями. До середини II століття до намої ери завдяки активізачії індійської писемності Харошті індійські елементи почали з'являтися на монетах і стали масовими. Було змінено не тільки легенду, але $i$ ваговий стандарт на індійський. І цее була найважливіша зміна.

Проблематика: вагомий масив індо-грецьких монет вже був виявлений до нашого часу, але тема залишалася недослідженою з кількох причин. Як правило, проблемні зони залишаються без розгляду та без відповіді. Головним чином ие сталося унаслідок вивчення такого типу монет ізольовано, далеко від ареалу знахідок, позбавлених стратиграфії, та ігнорування накопичених знань з даної теми. Ця ситуачія погіршилася через політичні потрясіння, ізольовані археологічні знахідки та записи з обмеженим доступом у поєднанні 3 відсутністю наукового підходу через несриятливі економічні умови, відсутність доступу до сучасних методів та технологій, дуже важливих для вивчення індогрецького монетного карбування. На жаль, дослідження індо-грецької монети залишається на периферії вивчення більш популярного та модного елліністичного світогляду.

Мета дослідження: У иій статті висвітлюються проблеми у вивченні монет індо-грецького карбування та інші чинники, які не були розглянуті, та труднощі на шляху наукових пошуків. Для вирішення проблем рекомендується більш сучасний технологічний підхід.

Наукова новизна: Більш технологічний підхід до вивчення індо-грецької монети покликаний розкрити таємнищі та усунути білі плями в їх історії. Тему карбування індо-грецької монети слід розглядати відокремлено від елліністичної монети, зважаючи на ї̈ унікальність.

Висновки: Сучасні археологічні розвідки та розкопки, орієнтовані на сучасні технології, у поєднанні з найновішими інструментами інформаційних 
технологій, включаючи використання сочіальних мереж, можна ефективно об'єднати в єдиний репозитарій, щоб створити нову сучасну базу даних знахідок монет індо-греків, щчо стане в нагоді історикам, археологам, науковиям, студентам та колекиіонерам.

Ключові слова: Індо-Греки, проблематика наукового дослідження, Бактрія, індійська нумізматика.

Two famous Indo-Greek kings, Pantaleon and Agathokles pioneered bilingual coins in the region with Brāhmī (hereon Brahmi) script alongside the Greek script on the obverse of their coins. This fact helped decipher the long-forgotten Brahmi script. Apollodotus I/Antimachus II/Eukratides were among the first to mint bilingual coins with Kharoșhī (hereon Kharoshthi) legend. This arrangement remained in practice till the disappearance of the Indo-Greeks. In 250 years of Greco-Bactrian coinage, close to 35 out of 45 rulers minted bi-lingual coins. The coinage of the Indo-Greeks helped in building their history. However, very scant archaeological remains and limited study otherwise proved it difficult not only to establish genealogy and timelines of the Indo-Greeks but also important areas related to numismatics which can throw light on commerce, economics remained unexplored and understudied. Though coinage helped in building their history a little, the challenges related to numismatics and archaeology are still to be addressed. Reigns of many rulers in a short period, metrology, monograms, and field marks, different weight standards and script, near absence of archaeological exploration, and hoard study are some of the issues which need attention.

One of the oldest Buddhist stupa at Sanchi, in the State of Madhya Pradesh in Indias, depicts the life and times of $3^{\text {rd }}$ Century BCE India. People from different ethnicity of foreign origin are seen around a stupa on the mural of a gate.

Pieces of evidence of interactions with people from a faraway land are found in abundance from the time of the Indus Saraswati Civilization. The interactions were cultural, commercial, or a try to conquest. It was a long-cherished dream of Alexander of Macedonia to conquer India. He had to leave India with the desire unfulfilled. But his generals were asked to stay back (or had chosen to stay back) to hold the conquered territory we know as Bactria. Few tried to expand.

From the southern bank of the Caspian Sea to the west of the Indus, these Bactrian generals held sway. Time passed. The rulers changed, intermingled with the people, adopted Indian scripts and languages, and are now known as Indo- Greeks.

Heliodorus, the Greek Ambassador sent by Antialkidas (late $2^{\text {nd }}$ Century BCE) to the court of Indian Shunga dynasty king Bhagbhadra is a well-known fact. Garuda Column erected by Heliodorus in the heart of India at Besnagar, Vidisha in the state of Madhya Pradesh (MP) stands today as a testimony to the deep and warm relations the people of India had with Greco-Bactrian rulers of the ancient time. 
The coinage of the Indo-Greeks was very simple as far as striking was concerned. The obverse depicted the bust of the ruler and mostly, very short legend around the bust. The reverse had deities, animals, and other motifs with Prākita (Prakrit) legend inscribed around in Kharoshthi. Monograms/field letters were positioned in the reverse, mostly below or beside the motifs.

\section{Challenges and Problem Areas}

Besides who, where, and when; what challenges are faced by the numismatists and problem areas which, if addressed methodically can unlock mysteries and history of the Indo-Greeks.

As observed recently: "Tens of thousands of these coins exist today, dispersed in collections, both public and private, across the globe, not just in Europe, the UK, and the US, but, rather importantly, in Afghanistan, Pakistan and India as well. With standard reference works out of print and only existing in French and English, it is difficult for scholars and those working in cultural institutions holding these coins to engage with the material at several different levels, including not just basic cataloging but advanced research too. Lacking, in many cases, basic and accurate typological information describing where, when, and who produced the coins, the potential of these collections to serve as historical resources remains currently locked."1

\section{Switching from Brahmi to Kharoshthi}

Only two Indo-Greek rulers have minted coins with Brahmi, the rest of the rulers used Kharoshthi. What made most of the rulers adopt Kharoshthi when their immediate two predecessors adopted Brahmi on their bi-lingual coinage; viz., Agathocles and Pantaleon. It would be really interesting to find out the reason behind this switch. Brahmi was a pan-Indian script. Kharoshthi was only limited to the northwestern part of ancient India. There have to be some compelling reasons.

\section{Copper Coins: Variations in Weight and Metrology}

Here, for a numismatist, arises the first challenge to establish a proper relationship of denominations vis-à-vis their weight and metal. E.g., How many units of copper of what weight was equivalent to a drachm (attic and Indian standard)?

No gold coins have been reported issued by the Indo-Greeks. There were silver Drachms, tetradrachms, and decadrachms (issued occasionally) minted in very large numbers. And, there were copper units of different weights. Some copper units were as heavy as 43 grams (16 Units?). Names like Obol, Hemi- obol, Chalkons, and DiChalkon are used for different copper coins by some numismatists, cataloguers, and dealers but the denominational relations among them and with the silver drachm needs deep study.

We find copper coins of different weights as 16 Units. This is ambiguous and needs to be researched well. It is for sure that these coins of different weights were known with different names. But no reliable record/absence of record makes it very difficult to establish a logical connection of different weight copper coins. Fortunately, this is not a problem when it comes to drachm and its multiples. However, was there a 
standard for metal purity while minting a particular denomination is not clear. It is also not clear whether the metal purity standards were the same throughout the rules of the Indo-Greeks. Neither the metrology.

\section{Changing Attic weight standard to Indian standard}

It was Apollodotus I (174-165 BCE) who, it is believed, pioneered/introduced/adopted Indian standard over attic standard.

What made the change in the standard?

Other than casual references about the changes in weight standard from Attic to Indian, we, in reality, do not know what circumstances were prevailing that forced the change in the weight standard - a very important component of coinage and economics.

This riddle needs to be solved - why the Indo-Greeks changed weight standards from Attic to Indian. What were the circumstances that lead to the reduction of weight and adoption of the Indian weight standard?

Taking into consideration historical fact, the possible reasons for changing the weight standard could be:

Economic Conditions must have changed drastically in that particular time frame.

Exchange Rate issues might have influenced the change in weight standards.

Purity disparity could be another reason

No options were left because of the turmoil in the western and southern part of the kingdom and no option was left but to adopt the Indian weight standard to remain relevant.

It is difficult to find purity related research on Indo-Greek coins. It is high time such studies are carried out and findings are presented for wider dissemination. The relationship with weight standards and purity standards of Indo-Greek coins need to be understood in totality. This study may reveal the economics of their time.

\section{Uncertainty about Mints}

Find spots cannot decisively ascertain mint town. Especially, when the find spots are devoid of historical and archaeological references, it becomes difficult to firmly establish any hypothesis. In the troubled regions of Central Asia and especially Afghanistan and along its borders with the neighbors it is difficult to carry out any meaningful onsite research. On an almost daily basis, historical and archaeological evidence is unknowingly damaged and destroyed.

The near absence of the structures belonging to cities, monuments, and meaningful complete inscriptions on rock or manuscripts makes it difficult to ascertain critical facts. The remaining ones are either partially destroyed or majorly damaged and not useful for establishing or corroborating numismatic pieces of evidence.

Ambiguity about Monograms, Field Letters, and Mint Marks (?)

There are approximately 150-200 monograms/field letters found on the coins of Indo-Greeks and their successors (with Greek, Brahmi, and Kharoshthi letters). Some 
are complex monograms while some are compound Brahmi and Kharoshthi letters. A detailed study of these symbols is always missing. It would be naïve to think that these symbols are just mint marks - as it is difficult to imagine so many mint towns in a short time and relatively small geography.

\section{Ancestry and Relationships Among the Rulers}

In the case of Western Kshatraps, who were at some point in time were the contemporaries of the Indo-Greeks, introduced coins with the pedigree with the name and title of the ruler along with the name and title of his father. It became easier to establish the ancestry in this case.

For Indo-Greeks, it is difficult to establish whether some of the rulers were contemporaries or predecessor/successor. In some cases, in a short bracket of a period, we see many rulers. There must have been dynasties; ancestral and other

relations among the rulers. All the ambiguities in this regard need to be addressed. E.g., Apollodotus I, Antimachus II, and Eukratides. Or Agathocles and Pantaleon. There are many examples.

\section{Theo as God (Indian for Deva/Deo = Deity) $\Theta E O$ and Theopator

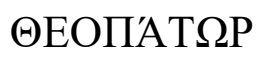

\section{(Deva-Putra $=$ Son of God)}

Initially, Bactrian rulers used the title $\Theta E O$, e.g., Antimachus. The Indian word for the same is Deo, phonetically similar, almost. The Indo-Greek coins have been so far studied with the western lens. While the Indic part is either ignored or not taken into account in its real sense makes the research efforts incomplete. The reverse side of the Indo-Greek coins has typical Indian motifs, legends, language, and translation of Greek legend on the obverse. A holistic view of keeping the „Indian-ness" and "Greek" facts is paramount while studying these coins. The closeness of the IndoEuropean languages brings out phonetic similarities and are found in the legends of the coins cannot be ignored.

\section{Access to Archaeological Records/Stratigraphy/Hoard Studies}

Many Central Asian countries gave limited access to their archaeological records. Few European nations were given limited access. The region was a war zone and witnessing political upheavals. It was difficult to think of doing on-site research or visiting those archives/museums for deep research till the recent past.

In these digital ages, these museums and archives are still out of bound as they have not yet kept up with the changing times. Very few museums have made their collection available online.

Archaeological pieces of evidence are destroyed knowingly and unknowingly by certain elements. Coins are melted down and hoards are sold out without records and proper study ${ }^{2}$. A foolproof stratigraphically survey will remain a pipe dream for researchers.

\section{Where are the Countries of the Graeco-Bactrian Region in the Discourse}

It is a fact that the numismatics research happening is devoid of any significant 
involvement of the countries from the ancient Greaco-Bactrians/Indo- Greek region. The records and artifacts have been either destroyed, stolen, or have been misplaced in countries like Afghanistan. Afghanistan, Uzbekistan, and Tajikistan were part of the Greco-Bactrian region in their ancient past. Besides India, they are important stakeholders in any Indo-Greek studies. But, we do not see their participation. Archaeological context to hoards found in these countries must be preserved and studied well by involving them and by increasing their participation in discourses.

\section{Absence of Network of Scholars, Absence of Affordable Publications}

As of today, the major affordable source to study Indo-Greek coins is the internet. The websites of auctioneers dealing in Oriental coins are the major source of coinage, images, and historical descriptions. The scholarly work is scanty and available publications are either unaffordable for scholars and students or out of print. Most of the websites include Greek legend in the lot description while Kharoshthi (or its transliteration) is left out. Mitchineres catalogs are very helpful in this regard. But, they are not affordable for student scholars and young collectors. Moreover, they are out of print and the books have become rare themselves!

While we find an enormous amount of discussion and publications of Roman/ Greek, Byzantine, Islamic, and US coins on internet boards and social media, the IndoGreek coins are very rarely discussed.

Mr. Simon Glenn has vividly described this issue in his paper "GraecoBactrian and Indo-Greek Coins - A Bibliography of the Numismatics of the Hellenistic Far East". Here also, the issue is "Hellenistic Far East" which shifts the focus from "Indo-Greek". Though the problem is very well highlighted

All in all, the crux of the problem is tying Graeco-Bactrian (GB) and IndoGreek (IG) coins with Hellenistic coinage. Given the humungous size of the Hellenistic coinage, the GB/IG are not given enough attention and these coinage have been neglected thus far.

\section{SOLUTIONS - THE WAY FORWARD}

\section{De-coupling of BG/IG Archaeology and History from Hellenistic Study}

The first task at hand is to give special attention to GB/IG coinage and decoupling from the Hellenistic purview. The IG coinage has its own set of problems, own distinctive history tied with local environs and politics.

\section{Special Attention and Scholarship/Museum Fellowship for BG/IG Coinage}

Except for the significant work done by Osmund Bopearachchi, it is very difficult to find dedicated work on BG/IG coinage. To get a meaningful insight, other than his work museum catalogs prepared in the last century no meaningful scholarly work is available worth quoting except papers highlighting sundry problems regarding identifying, deciphering, and forgery-related matters. A couple of dedicated scholarships and fellowships for deep study only for BG/IG coinage will go a long way in building up meaningful research in the field 


\section{Archaeological Context and Hoard Study}

Completely missing is the archaeological stratigraphy details of hoards found. No worthwhile study is possible if this context is missing. A re-look and review with archaeologists and scholars dedicating enough time and energy to build-up meaningful corpus and making it available to scholars at archaeological institutes and museums in an online format as well will go a long way to remove the adage of total neglect on the subject.

\section{Use of Data Science and Analytics}

Providing APIs for analytics of the scholarly work and websites will make the study of the BG/IG coinage more research-oriented to data-driven numismatists.

Using the emerging technology for dissemination of the findings on:

\section{Social Media - Twitter, Instagram, and Pinterest}

The most powerful tool for knowledge sharing in the modern age is social media. A few years ago there were moderated forums that provided a platform to discuss issues of numismatics. Social media has added to the possibilities of wider and free sharing of knowledge.

Nowadays, more user-friendly platforms like Instagram, Pinterest, and microblogging sites like Twitter are providing the much-needed environment to promote numismatics and archaeology.

Given the reach of these social media platforms; museums, institutions, and government bodies can make maximum use of them to promote numismatics and archaeology. These platforms should be moderated by subject experts and allow the collectors, scholars, and students to freely interact and express their insights into the subject.

\section{Fellowships and Scholarships}

Fellowships and Scholarships need to be provided to further the study as IndoGreek coinage is a field that connects the ancient West and the East. There is much to learn from this historically important epoch. IT shows how the co- existence of two different civilizations with different philosophies enriched history of the Central Asia and brought them closer.

\section{Symposiums, Workshops, and Seminars}

Ironically, there is negligible or non-existent Greek scholarly work available on Indo-Greek coinage. In all future endeavors to study Greco-Bactrian/Indo- Greek coinage, this fact should not be ignored. Proper platforms should be promoted in India and Greece involving nationals/institutes and scholars from the countries mentioned above to give it a needed representation. Uzbekistan, Tajikistan, and Afghanistan"s archaeological records need to be compiled, translated, and uploaded on websites and discussed on social media for a deep understanding of Bactrian archaeology and numismatics. History, Archaeology, Numismatics of this region along with India and Greece with Central Asia need to be studied in totality to fill the gap and address the unanswered questions. 
In all future studies these countries need to be involved, scholars are to be trained, and archaeological records are to be updated and uploaded with simultaneous fresh studies. This will be an ongoing project. Numismatics and Archaeology going forward hand in hand.

Once these countries are free of turmoil, seminars and workshops should be conducted in their regions clubbed with visits to archaeological sites. A proper funding mechanism is a need of the hour for this enterprise.

And, to bring these elements together, there is no better tool than social media to start with.

Once a critical and significant amount of insight and data is generated, the whole Indo-Greek coinage can be given a fresh look by bringing in the spotlight all the above-mentioned problem areas. And the research is to be continued.

This may eventually throw light on the economics of the Indo-Greeks!

\section{Bibliography:}

http://numismatics.org/pocketchange/oxus-indus/

Neville Agnew; Janet Bridgland (eds.). Of the past, for the future: integrating archaeology and conservation: proceedings of the conservation theme at the 5 th World Archaeological Congress, Washington, D.C., 22-26 June 2003. Los Angeles, Calif.: Getty Conservation Institute. p. 270.

\section{References}

Allan, J. (1951): „Notes on the punch-marked, local Taxilan and Greek coins ${ }^{\text {ee }}$ in Altekar, A. S. (1947b): „Some rare and interesting Indo-Bactrian coins ${ }^{\text {ce }}$, Journal of the Numismatic Society of India 9/ 1, 16-23. [in English].

Bhandare, Shailen (2007): „Not just a pretty face: interpretations of Alexander"s numismatic imagery in the Hellenic East ${ }^{\mathrm{ee}}$ - Memory as History: The Legacy of Alexander in Asia, eds. H P Ray and D T Potts. [in English].

Bopearachchi, Osmund (1991): Monnaies Gréco-Bactriennes et Indo-Grecques, Bibliothèque Nationale de France[in French].

Bopearachchi, Osmund (1993): Catalogue of Indo-Greek, Indo-Scythian and IndoParthian Coins of the Smithsonian Institution, Washington D.C. [in English].

Cunningham, A. (1840a), „Notice of some counterfeit Bactrian coins ${ }^{e e}$, Journal of the Asiatic Society of Bengal 9, 393-396. [in English].

Cunningham, A. (1846), „An attempt to explain some of the monograms found upon the Grecian coins of Ariana and India ${ }^{e e}$ NC 8, 175-197. [in English].

Cunningham, A. (1866), „Coin of the Indian prince Sophytes, a contemporary of Alexander the Great ${ }^{\mathrm{ee}}$, NC, new series, 6, 220-231. [in English].

Cunningham, A. (1884), Coins of Alexander's Successors in the East, London. [Collection of articles published in Numismatic Chronicle from 1868 onwards. [in English]. 
Dani, A H (1991) Bactrian and Indus Greeks: A Romantic Story and their Coins, Lahore: Lahore: Lahore Museum. [in English].

Dani, A. H. (1992), „Greek monograms "e in D. MacDowall, S. Sharma, and S. Garg (eds), Indian Numismatics, History, Art, and Culture: Essays in Honour of Dr. P.L. Gupta, vol. 1, 99-114, Delhi: Agam Kala Prakashan. [in English].

Gardener, Percy (1886): Catalogue of Indian Coins in British Museum - Greek and Scythic Kings of Bactria and India, 1886, 9-66[in English].

Gupta, P L (1987): Numismatics and Archaeology - 2nd International Colloquium. [in English].

Gupta, PL (2016): Coins. [in English].

Handa, Devendra (2007): Tribal Coins of Ancient India, J. Marshall, Taxila: Volume II Minor Antiquities, 853-863, Cambridge University Press. [in English].

Lahiri, A. N. (1958), „The case for a second Menander"e, Journal of the Numismatic Society of India 20/1, 71-73. [in English].

Lahiri, A. N. (1965) "A Corpus of Indo-Greek Coins" Poddar Publications. [in English].

Lahiri, A. N. (1967/68): „Metrology of the Indo-Greek silver coins ${ }^{\text {,e }}$ Journal of Ancient Indian History [in English].

Marshall, J. H. (1953): "Taxila: An Illustrated Account of the Archaeological Excavations", Cambridge University Press. [in English].

Mitchiner, Michael (1976): Indo-Greek and Indo-Scythian Coinage Vol I to IX [in English].

Ojha Gouri Shankar H, Dr.(1971): Bharatiya Prachin Lipimala (The palæography of India ), 3rd edition [in English].

Pieper Wilfried (1998): Ancient Indian Coins Revisited, [in English].

Senior, Robert C (2000); Indo-Scythian Coins And History. [in English].

Whitehead, RB (1914): Catalog of the Coins in the Punjab Museum, Lahore, Vol I. [in English]. 


\section{Illustrations}

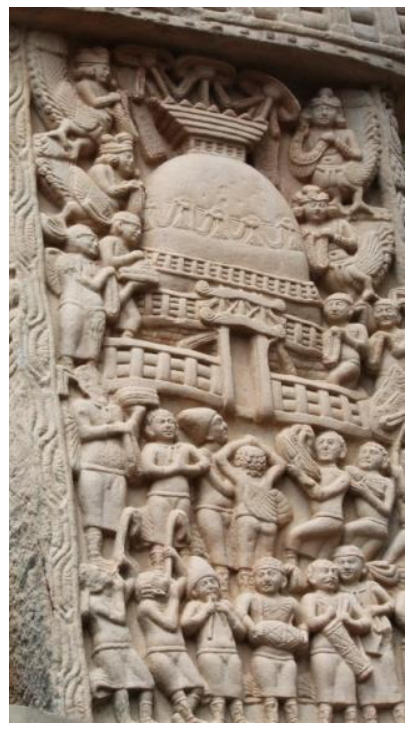

Pic. 1. Foreigners at Sanchi, India $-3^{\text {rd }}$ Century BCE (Photography: Bimal Trivedi)

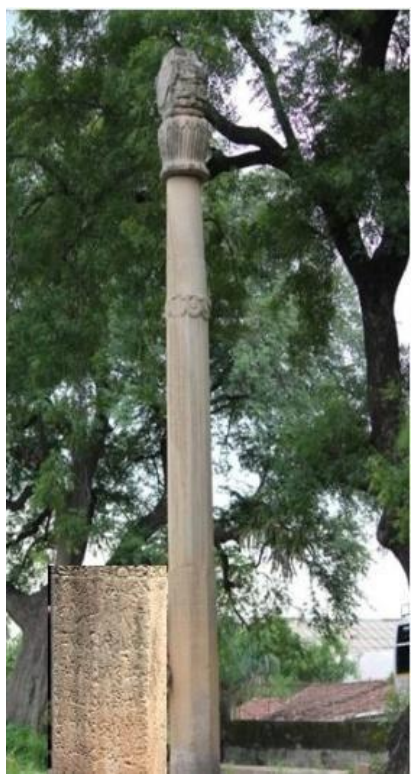

Pic. 3. Garuda Column Erected by Greek Ambassador to India, $2^{\text {nd }}$ Century BCE

(MP, India, Photography: Bimal Trivedi)

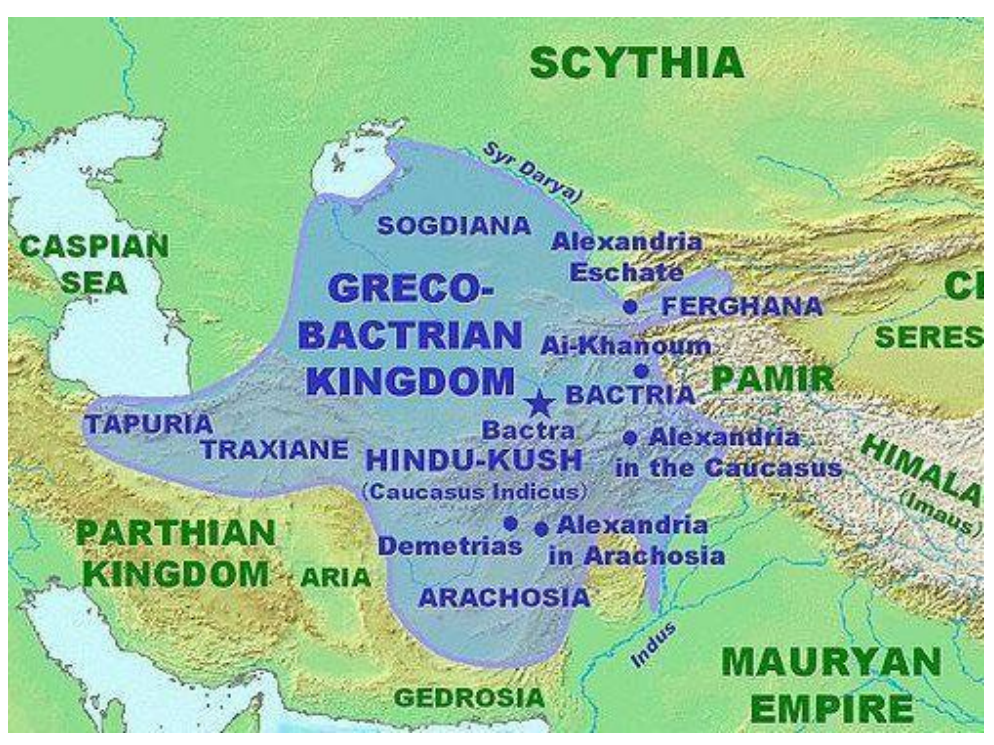

Pic. 2. Image source: wiki

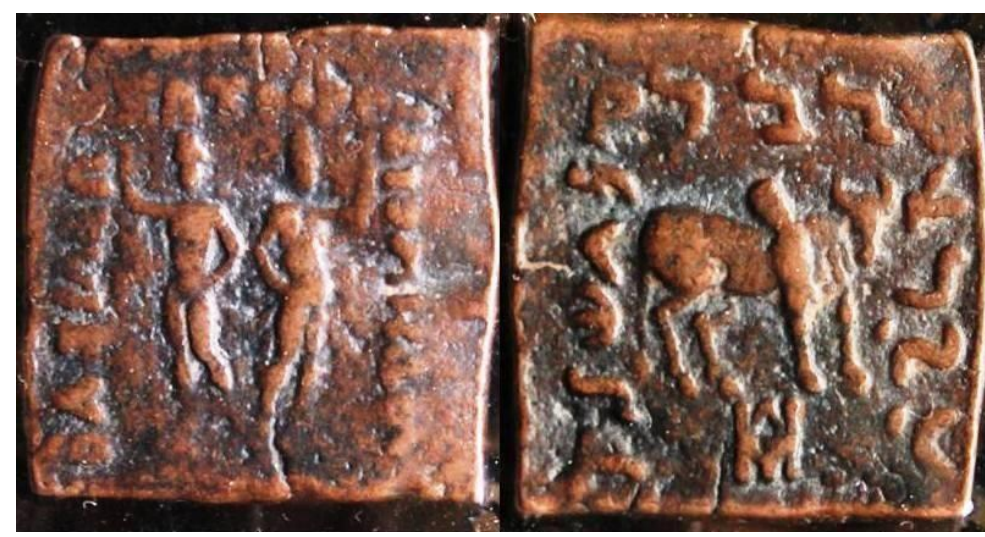

Pic. 4. Diomedes ${ }^{\text {ee }}$ Copper Unit: Monogram below the Bull (Bimal Trivedi collection, Mumbai)

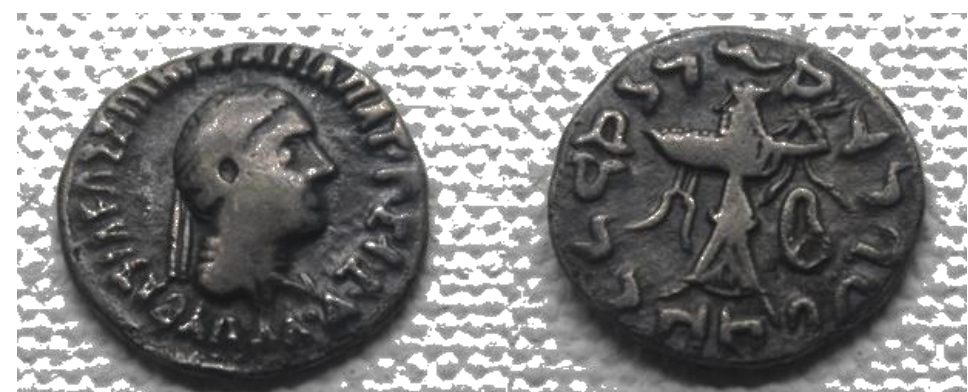

Pic. 5. Drachm of Apollodotus II - Monogram/Symbol. Below the Right Hand of the Figure on Reverse (Bimal Trivedi collection, Mumbai) 


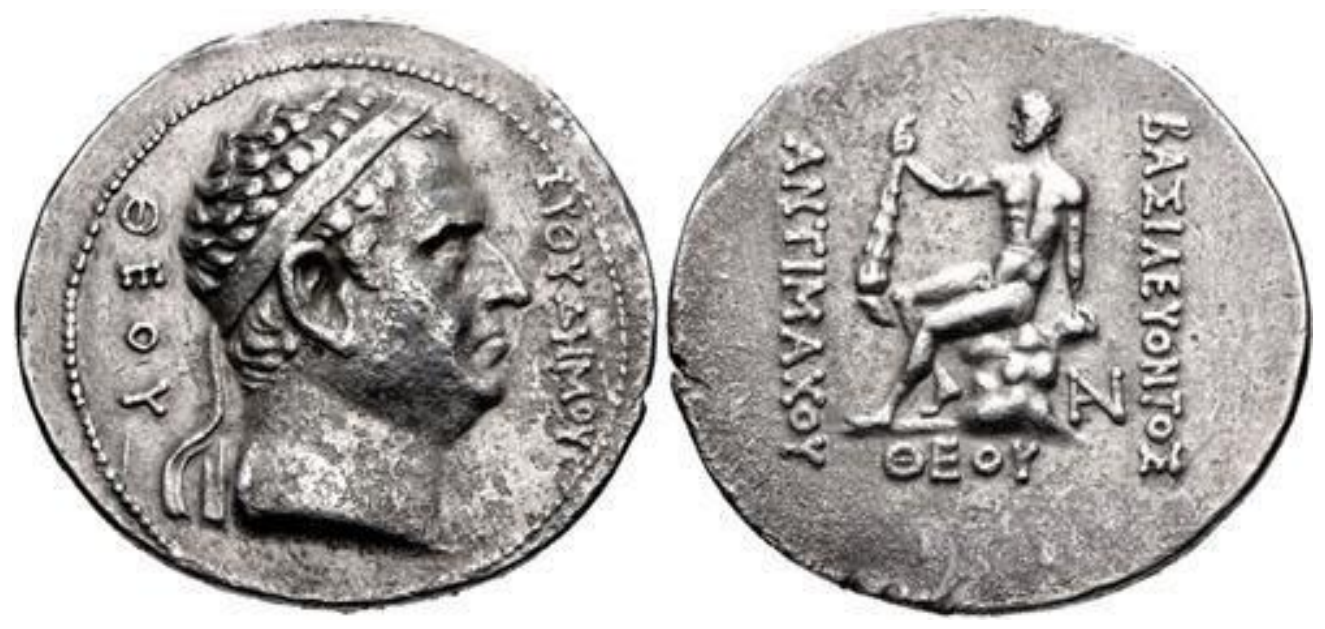

Pic. 6. The Greco-Bactrian Kingdom. Antimachos I Theos. Circa 180-170 BC. AR Tetradrachm (Image: CNG Coins) 